\title{
Evaluating the Relationship Between Migration and Participation in Undeclared Work: Lessons from Bosnia and Herzegovina
}

Colin C. Williams ${ }^{\star}$, Adnan S. Efendic ${ }^{\star *}$

\section{Summary}

Until now, studies of the relationship between migration and participation in undeclared work have adopted as their unit of analysis the activity of specific migrant groups in their host country. In this paper, a novel approach is pursued by adopting a different unit of analysis. To examine the relationship between migration and participation in undeclared work, the activity of the domestic population in their home country is analysed according to their previous migration activity. To do so, data is reported from a 2015 survey of 6,021 randomly selected respondents aged between 16 and 65 years old in Bosnia and Herzegovina. The finding is that undeclared work is the sole source of earnings for $21 \%$ of the total labour force, but for $26 \%$ of those who have spent more than three months abroad, $18 \%$ of internal migrants and $22 \%$ of those who have not migrated either internally or abroad. After controlling for other determinants of undeclared work, a Probit regression analysis finds a significant $8 \%$ higher probability of participation in undeclared work for those who have spent time out of the country compared with the non-migrant population. The theoretical and policy implications are then discussed.

Keywords: informal economy, migration, Bosnia and Herzegovina.

JEL: H26, J46, K42, O17, P37

\section{Introduction}

Deviewing the literature on the Trelationship between migration and participation in undeclared work, the unit of analysis adopted in nearly all studies is the activity of specific migrant groups in their host country (Batnitzky and McDowell, 2013; Edwards et al., 2016; Ram et al., 2009; Sassen, 2009; Sepulveda et al., 2006; 2011; Shahid et al., 2017; Theodore et al., 2015). The common finding is that migrant populations often engage in undeclared work in their host nations (Shahid et al., 2019; Urzi and Williams, 2017; Vershinina et al., 2011; 2018), and the resultant debate then revolves around whether they undertake undeclared work out of necessity or choice (Ram et al., 2017; Sepulveda et al., 2011). In this paper, a fresh perspective is offered on the relationship between migration and participation in undeclared work. Rather than examine whether some migrant group engages in undeclared work in their host country, a different unit of analysis is here adopted. The aim of this paper is to

\footnotetext{
* University of Sheffield; Efendic - University of Sarajevo School of Economics and Business

** University of Sheffield; Efendic - University of Sarajevo School of Economics and Business
} 


\section{Articles}

evaluate the relationship between migration and participation in undeclared work by taking as its unit of analysis the activity of the domestic population in their home country according to their previous migration activity. Those citizens who have spent more than three months abroad (here termed "external migrants") are compared with those who have migrated internally within a country (here termed "internal migrants") and those who have not migrated internally or externally ("non-migrants"), in terms of their participation in undeclared work. To do this, a 2015 survey of 6,021 randomly selected respondents aged between 16 and 65 years old in Bosnia and Herzegovina is reported.

This paper therefore advances knowledge on the relationship between migration and undeclared work in three important ways. Conceptually, it adopts a new lens to analyse this relationship. Rather than examine the activity of migrant groups in their host country, this paper for the first time, so far as is known, examines the activity of the domestic population in their home country according to their previous migration activity. This will provide a fresh perspective on the relationship between migration and participation in undeclared work. Empirically, meanwhile, this paper reports the first known survey results of the level of participation in undeclared work of the domestic population in their home country according to their migration activity. Finally, and in terms of policy advances, this paper explores the policy implications of the finding that external migration increases the subsequent likelihood of participation in undeclared work.

In the next section therefore, a review is undertaken of previous studies on the relationship between migration and participation in undeclared work. This will reveal that it is nearly always the case that the activity of a migrant group in their host country is the unit of analysis, and that this suffers from several shortcomings, such as that it does not reveal whether migrant populations are more likely to engage in undeclared work than non-migrant groups. The outcome is the advocacy of an alternative unit of analysis to overcome these problems, which examines the relationship between migration and participation in undeclared work by examining the participation in undeclared work of the domestic population in their home country according to their previous migration activity. The outcome is a set of hypotheses on the likelihood of participation in undeclared work of external migrants, internal migrants and non-migrants. The third section introduces the data and methods used to do so, namely a 2015 survey of 6,021 randomly selected working age respondents in Bosnia and Herzegovina. The fourth section then reports the findings whilst the fifth and final section explores the implications for theory and policy, along with the limitations of the study and future research required.

At the outset, a definition of undeclared work is required. Reflecting the consensus among both policy makers and academics, undeclared work here refers to paid activities not declared to the authorities for tax, social security and/or labour law evasion purposes when they should be declared (European Commission, 2014; Jones et al., 2006; OECD, 2012; Ram et al., 2007; Schneider, 2013; Williams, 2004; 2006; Williams and Windebank, 1998).

\section{Literature review: the relationship between migration and participation in undeclared work}

For much of the twentieth century, the view was that undeclared work would disappear with development (Geertz, 1963; Gilbert, 1998; Lewis, 1959). However, in the last few decades, it has been recognised that undeclared work is far from declining, and 


\section{Articles}

that it is either remaining steady or growing in many countries and global regions (ILO, 2018; Williams, 2019; Williams and Schneider, 2016). The result has been a burgeoning literature on undeclared work. This has largely focused upon estimating its magnitude using either direct surveys methods or indirect proxy measurement methods (e.g., for reviews, see Nezhyvenko, 2019; Schneider and Williams, 2013, 2016; Williams, 2014).

Beyond measuring its size, there has also been a smaller emergent focus upon the character of undeclared work. On the one hand, this scholarship has unravelled the characteristics of various types of undeclared work ranging from unregistered employment (Gashi and Williams, 2019), through envelope wages (Hazans, 2011; Horodnic, 2016; Williams and Yang, 2017) to bogus selfemployment (Williams and Horodnic, 2019). On the other hand, it has begun to explore who engages in undeclared work. Often the starting point has been the long-standing "marginalization" thesis which asserts that groups marginalized from the formal labour market are more likely to engage in undeclared work, such as women, younger age groups, the less educated, and rural populations (Ahmad, 2008; Castree et al., 2004; Katungi et al., 2006). It is within this latter stream of scholarship on the "marginalization thesis" that the study of migrant populations and their participation in undeclared work is situated.

Examining this scholarship, nearly all studies analyse the participation of migrant groups in undeclared work in their host countries. For example, there have been studies of migrant groups in London's hospitality sector (Batnitzky and McDowell, 2013), the undeclared work practices of Pakistani migrants in a western European city (Shahid et al., 2017, 2019), Tunisian and Romanian migrants working in the agricultural sector in Sicily (Urzi and Williams, 2017), Asian
Evaluating the Relationship Between Migration

and Participation in Undeclared Work

migrants in western cities (Ram et al., 2009), migrant youths engaged in entrepreneurial endeavour in rural Ghana (Afreh et al., 2019) and Ukrainian entrepreneurs in the UK (Williams et al., 2012). Common to all these studies is that the unit of analysis is specific migrant populations in their host countries.

Grounded in the wider literature on the "marginalisation" thesis, much of this literature on specific migrant populations in their host country has adopted a structuralist lens and viewed their participation in undeclared work as arising out of their "exclusion" from the formal labour market and their undeclared activity as often exploitative low-paid work (Alberti, 2015; Clark and Colling, 2016; Edwards et al., 2016; Gilad and Levine, 1986; Gottfried et al., 2016; Roglay, 2007; Routh, 2011). Such individuals often face discrimination from the indigenous population, lack relevant cultural knowledge and skills in the host country (language skills) and also access to host-country relevant social capital (social and business networks) (Neville et al., 2014). Yet similar to the wider literature on undeclared work, a stream of thought has asserted that migrant activity in the undeclared economy can sometimes be driven also by voluntary "exit" rationales (Sassen, 2009; Snyder, 2004). For example, it has been asserted that migrants engage in undeclared work in their host country due to not only institutional and structural factors leading to the marginalisation of such workers from the formal labour market but also social and cultural ties and obligations (Edwards et al., 2016; Ram et al., 2017; Shahid et al., 2019) and access to informal sources of finance and labour through ethnic ties and/ or shared cultural values and language use (Vershinina et al., 2011). Drawing inspiration from institutional theory (North, 1990), undeclared work by migrant groups has been consequently viewed as illegal but socially legitimate endeavour that arises when the 


\section{Articles}

norms, values and beliefs of these migrants are not in symmetry with the laws, codes and regulations of the formal institutions (De Castro et al., 2014; Kistruck et al., 2015; Siqueira et al., 2014; Thai and Turkina, 2014; Webb et al., 2009; 2013; 2014).

In recent years, this has found expression in 'mixed embeddedness' theory (Kloosterman, 2010) which has been increasingly used to explain the engagement of migrants in undeclared work in their host countries (e.g. Jones et al., 2006; Ram et al., 2006, 2007). Kloosterman's theory of mixed embeddedness (2010) argues for more attention to the institutional arrangements in which ethnicminority workers are inevitably embedded. The theory places both the declared and undeclared work of migrant workers within a wider social, economic, regulatory and institutional framework, with special focus on the nature of the opportunity structures available to migrant workers. As such, it explains how the activity of migrant groups may not align with the formal laws, codes and regulations for a mix of reasons involving both necessity and choice.

All these studies are about the participation of specific migrant groups in undeclared work in their host countries. The problem with adopting migrants in their host country as the unit of analysis is several-fold. First, this focus prevents any understanding of whether these migrant populations are more likely to engage in undeclared work in their host country than the indigenous domestic population. Second, it prevents any understanding of the impacts of intra-national migration on engagement in undeclared work and third and finally, it prevents understanding of whether those who have spent time abroad are more likely to engage in undeclared work when they return to their home country.

Here, therefore, a new unit of analysis is adopted. The population of a country is divided in terms of its migrant activity. Those citizens who have spent more than three months abroad (here termed "external migrants") are compared with those who have migrated internally within a country (here termed "internal migrants") and those who have not migrated internally or externally, in terms of their participation in undeclared work. This not only provides a fresh perspective on the relationship between migration and participation in undeclared work but also advances understanding on the likely consequences of encouraging greater mobility. Until now, so far as is known, this has not been evaluated and little, if anything, is known about whether those who have migrated are more likely or not to engage in undeclared work than non-migrant groups. Here, therefore, we evaluate the relationship between migration and participation in undeclared work by testing the following propositions:

H1: Citizens who have spent more than three months abroad are more likely to participate in undeclared work than those who have not migrated internally or externally.

H2: Citizens who have migrated internally within a country are more likely to participate in undeclared work than those who have not migrated internally or externally.

\section{Data, variables and method}

\section{Data}

Bosnia and Herzegovina has a population of some 3.5 million, is a post-conflict society, a transition economy and a Western Balkans state that aspires to become part of the European Union. Institutionally, Bosnia and Herzegovina is composed of two entities, the Federation of Bosnia and Herzegovina (FBiH), Republika Srspka (RSBiH), and one district, 


\section{Articles}

the District Brcko of Bosnia and Herzegovina (DBBiH), including a cantonal level in $\mathrm{FBiH}$ and municipal level in both entities.

To evaluate the relationship between migration and participation in undeclared work, 6,021 interviews were conducted in 2015 by a professional market research agency with respondents aged between 16 and 65 years old in Bosnia and Herzegovina. The survey was conducted using computer-assisted telephone interviewing (CATI). The survey sample was designed so that each municipality had at least 40 participants and that the total number from all municipalities should be at least 6,000 . The participants were randomly selected. The technique of random selection by closest birthday was used. On first contact, the interviewers asked about the number of persons living in the apartment or house in the specified age range. The interviewers then conducted the interview with the household member whose birthday was closest to the date they are interviewing. If that person was not at home, they arranged call-backs, if possible. The software schedules five callbacks before omitting the number. This method ensures a random selection of respondents. In the final dataset, there are 44 observations per municipality on average. The minimum number of observations per municipality was 40 and the maximum was 46 .

\section{Variables}

The question used to identify those engaged in undeclared work is: "Do you have some informal job(s) or activities which bring you some income?". Those defined as undeclared workers are those who answered "Yes". However, for the regression analysis, those who simultaneously have declared
Evaluating the Relationship Between Migration

and Participation in Undeclared Work

jobs (i.e., those who work in the declared economy but generate some additional income through undeclared economic activities, such as providing repairs after regular working time) are excluded. Hence, those survey respondents who responded "yes" to the question "Do you have formal job which brings you income?", are excluded. Therefore, following Efendic and Williams' (2018) approach, the dependent variable for the regression analysis, undec/work, relates to those who participate in undeclared work but who do not simultaneously have a job in the declared economy.

To evaluate the relationship between participation in undeclared work and migration, independent variables on migration are required. Bosnia and Herzegovina has had three substantial waves of emigration in the recent past: i) emigration during the Former Yugoslavia period, mostly in 1970-1980's and for economic reasons; ii) 1992-1995 Bosnian war related emigrations, mostly forced; and iii) 1996 onwards, post-conflict related emigrations (Efendic, 2016). It is estimated that about 2.0 million people, or around $50 \%$ of the current population, is the size of diaspora in Bosnia and Herzegovina (Efendic et al., 2014). A certain proportion of population returned to the country immediately after the war or later. This context provides a fertile ground for the investigation of the effects of migration on participation in undeclared work. Here, therefore, three groups are differentiated: external migrants (those who have spent more than three months abroad and have returned to Bosnia and Herzegovina; $9 \%$ of the sample), internal migrants (those who migrated within the country during or after the

1 The data were collected as part of the RRPP supported project: 'Social capital, migration and economic performance - evidence from a post-conflict environment', implemented by CISAR, Sarajevo, 2014-2016.

Please see link for additional material (data set/questionnaire): https://seedsdata.unil.ch/project/ study-public-overview/153/2/. 


\section{Articles}

war; $26 \%$ of the sample), and the non-migrant population (65\% of the sample).

The control variables used, meanwhile, related to those characteristics that previous studies reveal are associated with participation in undeclared work (Williams and Horodnic, 2017). These include:

- Individual-level determinants - typical indicators linked to respondents such as age, gender, the level of education and area of living;
- Household-level determinants - include indicators linked to household income and wealth;

- Institutional environment determinants - the level of trust in institutions for the administrative structure in Bosnia and Herzegovina, and for the municipalities at the lowest administrative level.

The variables used in the analysis are reported in Table 1 along with a short explanation.

Table 1. Descriptive statistics of the variables used for empirical modelling

\begin{tabular}{|c|c|c|c|c|c|}
\hline Variable & Explanation of variables & $\begin{array}{l}\text { No. of } \\
\text { observations }\end{array}$ & Mean & Std. Dev. & $\begin{array}{l}\text { Don't } \\
\text { knows }\end{array}$ \\
\hline \multicolumn{6}{|c|}{ Dependent variable } \\
\hline undeclwork & Undeclared work: $1=$ yes; $0=$ no & 5,996 & 0.262 & 0.440 & $0.5 \%$ \\
\hline \multicolumn{6}{|c|}{ Independent variables } \\
\hline extmigrant & Migration status: $1=$ external migrant; $0=$ other & 5,954 & 0.090 & 0.286 & $1.1 \%$ \\
\hline intmigrant & Migration status: $1=$ internal migrant; $0=0$ ther & 5,954 & 0.261 & 0.439 & $1.1 \%$ \\
\hline nonmigrant & Migration status: $1=$ non-migrant; $0=$ other & 5,944 & 0.648 & 0.478 & $1.3 \%$ \\
\hline \multicolumn{6}{|c|}{ Control variables } \\
\hline age & Age of respondents: from 16 to 65 & 6,021 & 47.158 & 14.892 & $0.0 \%$ \\
\hline male & Gender: $1=$ male; 0 =female & 6,021 & 0.452 & 0.498 & $0.0 \%$ \\
\hline noeducat & Education: $1=$ no education; $0=$ other & 6,021 & 0.055 & 0.229 & $0.0 \%$ \\
\hline primary_ed & Education: $1=$ primary education; $0=$ other & 6,021 & 0.233 & 0.422 & $0.0 \%$ \\
\hline second_ed & Education: $1=$ secondary; $0=$ other & 6,021 & 0.543 & 0.498 & $0.0 \%$ \\
\hline high_ed & Education: $1=$ higher education; $0=$ other & 6,021 & 0.165 & 0.371 & $0.0 \%$ \\
\hline dontknow_ed & Education: $1=$ don't know; $0=$ other & 6,021 & 0.005 & 0.068 & $0.0 \%$ \\
\hline rural & Survey area: $1=$ rural; $0=$ urban & 6,021 & 0.484 & 0.500 & $0.0 \%$ \\
\hline forminc & Formal job: $1=y e s ; 0=$ no & 6,004 & 0.272 & 0.445 & $0.3 \%$ \\
\hline infinc & Informal job(s) or activities: $1=y e s ; 0=$ no & 5,992 & 0.335 & 0.472 & $0.5 \%$ \\
\hline nochild & Number of children: from 0 to 11 & 5,989 & 1.679 & 1.311 & $0.5 \%$ \\
\hline noincome & Household income $(\mathrm{HI}): 1=$ no income; $0=0$ ther & 6,021 & 0.070 & 0.256 & $0.0 \%$ \\
\hline inc_300 & HI: $1=$ up to 300 BAM; $0=$ other & 6,021 & 0.110 & 0.313 & $0.0 \%$ \\
\hline inc_700 & $\mathrm{HI}: 1=301-700 \mathrm{BAM} ; 0=$ other & 6,021 & 0.306 & 0.461 & $0.0 \%$ \\
\hline inc_700over & HI: $1=701-\ldots .$. BAM; $0=$ other & 6,021 & 0.276 & 0.447 & $0.0 \%$ \\
\hline inc_dknw & HI: $1=$ don't know; $0=$ other & 6,021 & 0.237 & 0.425 & $0.0 \%$ \\
\hline welfare & $\begin{array}{l}\text { Household welfare: (savings+ house + } \\
\text { insurance }+ \text { car }+ \text { computer) } / 5\end{array}$ & 5,700 & 0.462 & 0.242 & $5.3 \%$ \\
\hline
\end{tabular}




\begin{tabular}{|l|l|l|l|l|l|}
\hline Variable & Explanation of variables & $\begin{array}{l}\text { No. of } \\
\text { observations }\end{array}$ & Mean & Std. Dev. & $\begin{array}{l}\text { Don't } \\
\text { knows }\end{array}$ \\
\hline fbih & Region: 1=Federation BiH; 0=0ther & 6,021 & 0.573 & 0.495 & $0.0 \%$ \\
\hline rsbih & Region: 1 = Republika Srpska BiH; 0=0ther & 6,021 & 0.420 & 0.494 & $0.0 \%$ \\
\hline mnpc & Municipality code: from 1 to 143 & 6,021 & 73.259 & 41.409 & $0.0 \%$ \\
\hline stategov & $\begin{array}{l}\text { Could you please tell me how much confidence } \\
\text { you have in State government? Min 1 to Max 5 }\end{array}$ & 5,335 & 1.665 & 1.075 & $11.4 \%$ \\
\hline entgov & $\begin{array}{l}\text { Could you please tell me how much confidence } \\
\text { you have in Entity government? Min 1 to Max 5 }\end{array}$ & 5,305 & 1.677 & 1.090 & $11.9 \%$ \\
\hline locgov & $\begin{array}{l}\text { Could you please tell me how much confidence } \\
\text { you have in Local authorities? Min 1 to Max 5 }\end{array}$ & 5,316 & 1.739 & 1.147 & $11.7 \%$ \\
\hline
\end{tabular}

Analytical method

The dataset used for empirical modelling does not have standard missing values (i.e. unfilled responses), with "do not know" or "refuse to answer" responses very rare, accounting for less than $3 \%$ of the responses on average. These observations are omitted.

To evaluate the hypotheses, a probability empirical model (Probit) has been used as it fits the data (it is a binary response on the main question of interest - if respondents participate in undeclared work or not). This evaluates whether the independent and control variables influence participation in undeclared work. The model also includes 143 municipal dummies to capture the unobserved influences from municipalities. Cluster robust standard errors are estimated with municipalities as clusters. Such an estimation strategy minimises the possibility of omitted variables related to location and adopts a conservative approach to inference (Efendic and Pugh, 2018). The fully specified model can be written in the form of following equation:

$$
\begin{aligned}
& P(U N D E C L W O R K=1 \text { if } L A B F O R C E=1) \\
& =\Lambda\left(\beta_{0}+\hat{\beta}_{1} \cdot A G E+\hat{\beta}_{2} \cdot M A L E+\hat{\beta}_{3} \cdot \text { NOEDUCAT }+\hat{\beta}_{4} \cdot \text { PRIMARY } E D+\hat{\beta}_{5}\right. \\
& \cdot S E C O N D_{-} E D+\hat{\beta}_{6} \cdot R U R A L+\hat{\beta}_{7} \cdot \text { NOCHILD }+\hat{\beta}_{8} \cdot \text { NOINCOME }+\hat{\beta}_{9} \cdot I N C_{-} 300+\hat{\beta}_{10} \\
& \cdot \text { INC_700 }+\hat{\beta}_{11} \cdot \text { WELFARE }+\hat{\beta}_{12} \cdot \text { FBiH }+\hat{\beta}_{13} \cdot \text { STATEGOV }+\hat{\beta}_{14} \cdot \text { ENTGOV }+\hat{\beta}_{15} \\
& \cdot \text { LOCGOV }+\hat{\beta}_{16} \cdot \text { EXTMIGRANT }+\hat{\beta}_{17} \cdot \text { INTMIGRANT }+\hat{\beta}_{18-161} \cdot \text { Mncp_2toMncp_143) } \\
& +\hat{\varepsilon}
\end{aligned}
$$

\section{(Equation 1)}

The variables are explained in Table 1 above. $P$ refers to Probit estimation, $\wedge$ signifies a function of independent variables, $\hat{\beta}_{0-161}$ are coefficients to be estimated and $\hat{\varepsilon}$ is the model error term. We do not report the Probit-estimated coefficients as they do not provide directly useful quantification of the estimated relationships. Our interpretations rely on marginal effects after Probit estimation reported in Table 2.

\section{Findings: migration and participation in undeclared work}

Examining the active labour force (i.e., those in declared employment and those who state that they are actively looking for a job), the finding is that $9 \%$ of the total labour force are in declared work but also engage in undeclared work, whilst undeclared work is the sole source of earnings for $21 \%$ of the labour force. Participation in undeclared 


\section{Articles}

work, therefore, is far from a small peripheral activity in Bosnia and Herzegovina, which is consistent with Pasovic and Efendic (2018), who estimate that the level of undeclared economy in this year (2015) was around 30\% of GDP

Examining the influence of migration, the finding is that undeclared work is the sole source of earnings for $21 \%$ of the total labour force, but for $26 \%$ of those who have spent more than three months abroad, for $18 \%$ of internal migrants and $22 \%$ of those who have not migrated either internally within the country or abroad. These descriptive statistics therefore suggest that those who have spent time abroad are more likely to rely solely on undeclared work for their earnings than either internal migrants or those who have neither migrated either internally or abroad. Meanwhile, those who have not migrated either internally or abroad are more likely to rely solely on undeclared work for their earnings than those who have migrated internally.

To evaluate whether this remains the case when other variables are held constant and controlled for, Table 2 presents the marginal effects that result from a Probit regression analysis. Model 1 reports the marginal effects of individual- and household-level characteristics, Model 2 adds the region and the variable of trust in government,
Model 3 adds migration status whilst the full specification Model 4 includes all the variables. It is important to note the stability of the results across the models. Here, the results of the full specification Model 4 are analysed. This reveals that there is a higher probability of undeclared work by:

- men than women; there is a $6 \%$ higher probability of men participating in undeclared work;

- younger individuals; an increase in age by one year (16-65) reduces the probability of engaging in undeclared work by $1 \%$;

- less educated individuals; an additional level of education systematically decreases participation in the undeclared economy. For example, there is $21 \%$ higher probability of participation in the undeclared economy by individuals who did not complete their primary education in comparison to those with university degrees, and with a fully consistent pattern - lower education is associated with higher participation in undeclared economy;

- rural population; there is $4 \%$ higher participation in undeclared work by rural respondents compared with those from urban or suburban areas.

Table 2. Marginal effects after Probit estimates

\begin{tabular}{|c|c|c|c|c|c|}
\hline Variable & Explanation of the variables & Model 1 & Model 2 & Model 3 & Model 4 \\
\hline & & $\mathrm{dy} / \mathrm{dx}$ & $\mathrm{dy} / \mathrm{dx}$ & $\mathrm{dy} / \mathrm{dx}$ & $\mathrm{dy} / \mathrm{dx}$ \\
\hline \multicolumn{6}{|c|}{ Individual-level determinants } \\
\hline Male & Gender: $1=$ male; $0=$ female & $0.05^{\star \star \star}$ & $0.06 * \star \star$ & $0.05^{\star \star \star}$ & $0.06^{\star * \star}$ \\
\hline Age & Age of respondents: from 16 to 65 & $-0.01 * \star \star$ & $-0.01 * \star \star$ & $-0.01 * \star \star$ & $-0.01^{\star \star \star}$ \\
\hline Noeducat ${ }^{1}$ & Education: $1=$ no education; $0=$ other & $0.16^{\star}$ & $0.20 * \star$ & $0.16^{\star}$ & $0.21^{\star \star}$ \\
\hline Primary_ed ${ }^{1}$ & Education: $1=$ primary education; $0=$ other & $0.12^{\star \star \star}$ & $0.09 * \star \star$ & $0.13^{\star \star \star}$ & $0.10 * \star \star$ \\
\hline Second_ed ${ }^{1}$ & Education: $1=$ secondary; $0=$ other & $0.08^{\star \star *}$ & $0.07 * \star \star$ & $0.09 * \star \star$ & $0.07 * \star \star$ \\
\hline
\end{tabular}




\begin{tabular}{|c|c|c|c|c|c|}
\hline Variable & Explanation of the variables & Model 1 & Model 2 & Model 3 & Model 4 \\
\hline & & $\mathrm{dy} / \mathrm{dx}$ & $\mathrm{dy} / \mathrm{dx}$ & $\mathrm{dy} / \mathrm{dx}$ & $d y / d x$ \\
\hline rural & Survey area: $1=$ rural; $0=$ urban/suburban & 0.03 & $0.04^{*}$ & $0.03^{*}$ & $0.04^{*}$ \\
\hline \multicolumn{6}{|c|}{ Household socio-economic determinants } \\
\hline Nochild & Number of children: from 0 to 11 & 0.01 & 0.01 & 0.01 & 0.01 \\
\hline Noincome ${ }^{2}$ & Household income $(\mathrm{HI}): 1=0 ; 0=$ other & $0.26^{\star * *}$ & $0.26^{\star \star \star}$ & $0.25^{\star \star \star}$ & $0.26^{\star \star \star}$ \\
\hline Inc_300² & HI: $1=$ up to 300 BAM; $0=$ other & $0.17^{\star \star \star}$ & $0.18^{\star \star \star}$ & $0.16^{\star * *}$ & $0.17 * \star \star$ \\
\hline Inc_7002 & HI: $1=301-700$ BAM; $0=$ other & $0.07^{\star \star \star}$ & $0.08^{\star * \star}$ & $0.07^{\star \star \star}$ & $0.07^{\star \star \star}$ \\
\hline Welfare & Household welfare & $-0.15^{\star \star \star}$ & $-0.16^{\star \star \star}$ & $-0.15^{\star \star \star}$ & $-0.16^{\star \star \star}$ \\
\hline \multicolumn{6}{|c|}{ Institutional determinants } \\
\hline Fbih & Region: $1=$ Federation $\mathrm{BiH} ; 0=$ other & & $-0.10^{\star \star \star}$ & & $-0.09 * \star \star$ \\
\hline Stategov & Trust in state government & & 0.03 & & 0.03 \\
\hline Entgov & Trust in entity government & & 0.01 & & 0.01 \\
\hline Locgov & Trust in local government & & $-0.04 * *$ & & $-0.04^{\star \star}$ \\
\hline \multicolumn{6}{|c|}{ Migration determinants } \\
\hline Extmigrant $^{3}$ & Migration: $1=$ external migrant; $0=0$ ther & & & $0.07^{\star \star \star}$ & $0.08^{* * *}$ \\
\hline Intmigrant ${ }^{3}$ & Migration: $1=$ internal migrant; $0=$ other & & & -0.01 & -0.01 \\
\hline \multicolumn{2}{|c|}{ Number of observations } & 2,538 & 2,376 & 2,518 & 2,359 \\
\hline \multicolumn{2}{|c|}{ Municipal dummies included } & Yes & Yes & Yes & Yes \\
\hline \multicolumn{2}{|c|}{ Hosmer-Lemeshov $(\mathrm{HL})$, with groups of 10} & 13.78 & 10.67 & 11.17 & 11.90 \\
\hline \multicolumn{2}{|l|}{ Prob > chi2 } & 0.09 & 0.22 & 0.19 & 0.16 \\
\hline
\end{tabular}

Note: $\mathrm{dy} / \mathrm{dx}$ is for discrete change of dummy variable from 0 to $1 .{ }^{* * *},{ }^{* *},{ }^{*}$ denotes statistical significance at $1 \%, 5 \%$ and $10 \%$ respectively.

The omitted categories:

1. for education is the higher education (higher_ed);

2. for household income are categories of income greater than 700 BAM (inc_700over);

3. for migration status are those that have not migrated (nonmigrant)

Note, the estimated coefficients are rounded at two decimal places

Source: Authors' calculations using STATA 14 (STATA 14, StataCorp, Texas, USA).

Examining household-level determinants, the finding is that there is a higher probability of undeclared work by:

- lower-income households. For example, there is $26 \%$ higher probability of participation in undeclared work by individuals coming from households who have no regular income in com- parison with those with the highest income category (base).

- Materially poorer households (i.e., not having savings, a house, insurance, car, computer). There is a $16 \%$ smaller probability of engaging in undeclared work for individuals living in households who have one additional 


\section{Articles}

component that reflects material wealth (i.e., savings, or a house, or insurance, or car, or computer).

- Number of children has no significant effect on the participation in the undeclared economy.

Turning to the effects of institutional environment influences where we control for the trust in the state (i.e. national) level institutions, entity level institutions, and the local level institutions, there is a higher probability of participation in undeclared work by:

- Individuals who have lower trust in the local governments participate more in undeclared work, while higher levels of government (entity and national) are not statistically significant. This suggests the importance of local governments for tackling undeclared work;

- Participants from the Republika Srpska entity in comparison to $\mathrm{FBiH}$ entity;

- Finally, the municipal effects (127 municipal variables) are included to control for the effect of omitted influences at the municipal level and we do not interpret these results.

Examining the influence of migration on participation in undeclared work in the full specification model, the finding is that external migrants in Bosnia and Herzegovina (i.e. those who spent abroad more than three months and returned to Bosnia and Herzegovina; hence not being tourist) are significantly more likely to engage in undeclared work (confirming H1). Indeed, they report a $8 \%$ higher probability of participation in undeclared work compared with the non-migrant population. However, no significant differences are found between the internal migrant and non-migrant population in their participation in undeclared work (refuting H2). A further checking of the interaction between the trust in local government and external migration status does not report any significant effects. As the main limitation of our research we see a standard challenge associated with cross-sectional data, which is something that could be addressed in future research and data collections.

\section{Discussion and Conclusions}

To evaluate the relationship between migration and participation in undeclared work, this paper has analysed data from Bosnia and Herzegovina using the marginal effects from a probit regression analysis. This reveals that in Bosnia and Herzegovina, participation in undeclared work is significantly higher among those who have spent more than three months abroad. Here, the theoretical and policy implications of this finding are discussed.

Theoretically, this study reveals that there is a need to complement the conventional unit of analysis which examines the activity of migrant groups in their host country with this new unit of analysis when theorising the relationship between migration and participation in undeclared work. This takes the domestic population as the unit of analysis and disaggregates them by their migrant activity: external migrants, internal migrants and non-migrants. Adopting such a unit of analysis has revealed for the first time that domestic populations who have engaged in external migration and returned are subsequently more likely to engage in undeclared work in their home country. Therefore, international migration is associated with increasing participation in undeclared work. This is not solely due to migrant groups being more likely to engage in undeclared work in their host country, as previous studies have highlighted (Ram et al., 2009; Shahid et al., 2019; Urzi and Williams, 2017). It is also because those who have been abroad and then return to their home country are also significantly more likely to engage 


\section{Articles}

in undeclared work than non-migrant groups, even after controlling for other determinants of participation in undeclared work. What is now required is qualitative research with this group to explore their reasons for engaging in undeclared work, especially whether this is a result of exclusion or exit, as has been explored when examining migrant groups in their host country. Until this research has been conducted, explanations and theorisations regarding why this occurs will be supposition rather than an evidence-based finding.

Turning to the policy implications, these results display the specific populations that need to be targeted when tackling undeclared work. These include younger age groups, the less educated, rural populations and the less affluent regions. This analysis, in other words, provides a useful risk assessment of different populations to enable an evaluation of the validity of the currently targeted populations. One key group here identified which needs to be targeted are those who have been abroad in the past for more than three months and subsequently returned. Mobility is here shown to be associated with higher probability of engaging in undeclared work. Again, until qualitative research is undertaken to understand the reasons for this, policy solutions cannot be proposed.

Vertical trust, which refers to the low trust of citizens in government, viewed through the lens of institutional theory, is a measure of the asymmetry between the laws, codes and regulations of formal institutions and the norms, beliefs and values of citizens (Helmke and Levitsky, 2004; North, 1990). The greater this non-alignment, the greater is found to be the likelihood of participation in undeclared work (Williams and Shahid, 2015; Windebank and Horodnic, 2018). In line with this discussion, there is a consistency between our results and by Williams and Efendic (2019) who report systematically lower trust to institutions
Evaluating the Relationship Between Migration

and Participation in Undeclared Work

among external migrant (entrepreneurs) in this country. Future qualitative research needs to explore which institutions, if any, are not trusted by returning migrants. These can then become the focus for change to build greater vertical trust. Previous studies in other countries reveal compliance increases with improved procedural justice, which refers to citizens perceiving state authorities to treat them in a respectful, impartial and responsible manner (Murphy, 2005), procedural fairness, which refers to citizens believing they pay their fair share compared with others (Molero and Pujol, 2012) and redistributive justice, which refers to citizens believing they receive the public goods and services deserved for the taxes paid (Kirchgässner, 2011).

In sum, this paper has revealed for the first time that among domestic populations, citizens who have lived and worked abroad are more likely to engage in undeclared work than those who have not. Further research in other countries is now required to evaluate whether this is similarly the case elsewhere. If this paper stimulates such research, it will have fulfilled one of its intentions. If this paper also encourages deeper qualitative research on the reasons for this, along with an exploration of the policy implications, then it will have fulfilled its wider intention.

\section{References}

Afreh, B., Rodgers, P., Vershinina, N. and Williams, C.C., 2019. Varieties of Context and Informal Entrepreneurship: the mundane and lively entrepreneurial practice among migrant youths in rural Ghana. International Journal of Entrepreneurial Behaviour and Research, 25(5), pp. 996-1013.

Ahmad, A.N., 2008. Dead men working: time and space in London's ('illegal') migrant economy. Work, Employment and Society, 22(2), pp. 301-18. 


\section{Articles}

Alberti, G., 2015. Mobility strategies, "mobility differentials" and "transnational exit": the experience of precarious migrants in London's hospitality sector. Work, Employment and Society, 28(6), pp. 865-882.

Batnitzky, A. and McDowell, L., 2013. The Emergence of an 'Ethnic Economy'? The Spatial Relationships of Migrant Workers in London's Health and Hospitality Sectors. Ethnic and Racial Studies, 36(12), pp. 1997-2015.

Castree, N., Coe, N., Ward, K. and Samers, M., 2004. Spaces of Work: global capitalism and the geographies of labour. London: Sage.

Clark, I. and Colling, T., 2016. New insights into informal migrant employment: hand car washes in a mid-sized English city. Economic and Industrial Democracy. https://doi. org/10.1177/0143831X16669840

De Castro, J.O., Khavul, S. and Bruton, G.D., 2014. Shades of grey: how do informal firms navigate between macro and meso institutional environments? Strategic Entrepreneurship Journal, 8(1), pp. 75-94.

Edwards, P., Ram, M., Jones, T. and Doldor, S., 2016. New migrant businesses and their workers: developing, but not transforming, the ethnic economy. Ethnic and Racial Studies, 39(9), pp.1587-1617.

Efendic, A. and Pugh, G., 2018. The effect of ethnic diversity on income: An empirical investigation using survey data from a postconflict environment. Economics: The Open access, Open Assessment E-Journal, 12, pp. 1-34.

Efendic, A. 2016. Emigration intentions in a post-conflict environment: evidence from Bosnia and Herzegovina. Post-Communist Economies, 28(3), pp. 335-352.

Efendic, A., Babic, B. and Rebmann, A. 2014. Diaspora and Development - Bosnia and Herzegovina. Sarajevo: Embassy of Switzerland in $\mathrm{BiH}$.
Efendic, A. and Williams, C. C. 2018. Diagnostic report on undeclared work in Bosnia and Herzegovina. Sarajevo: Regional Cooperation Council.

European Commission, 2014. Employment and Social Developments in Europe 2013. Brussels: European Commission.

Gashi, A. and Williams, C.C., 2019. Evaluating the prevalence and distribution of unregistered employment in Kosovo: lessons from a 2017 survey. The South East European Journal of Economics and Business, 14(1), pp. 7-20

Geertz, C., 1963. Old Societies and New States: The Quest for Modernity in Asia and Africa. Glencoe, IL: Free Press.

Gilad, B. and Levine, P., 1986. A behavioural model of entrepreneurial supply. Journal of Small Business Management, 24(4), pp. 45-53.

Gilbert, A., 1998. The Latin American City. London: Latin American Bureau.

Gottfried, K., Shields, J., Akter, N., Dyson, D., Topkara-Sarsu, S., Egeh, H., Guerra, S., 2016. Paving Their Way And Earning Their Pay: Economic Survival Experiences of Immigrants in East Toronto. Alternate Routes: A Journal of Critical Social Research, 27, pp. 137-161.

Hazans, M., 2011. Informal Workers Across Europe: Evidence from 30 Countries, IZA DP No. 5871.

Helmke, G. and Levitsky, S., 2004. Informal institutions and comparative politics: a research agenda. Perspectives on Politics, Vol. 2, pp. 725-740.

Horodnic, I., 2016. Cash wage payments in transition economies: Consequences of envelope wages. Bonn: IZA

ILO, 2018. Women and Men in the Informal Economy: statistical picture, available at: http:// laborsta.ilo.org/informal_economy_E.html (last accessed 18 August 2015).

Jones, T., Ram, M. and Edwards, P., 2017. Shades of Grey in the Informal Economy. 


\section{Articles}

International Journal of Sociology and Social Policy, 6(9/10), pp. 357-373.

Jones, T., Ram, M. and Edwards, P., 2006. Ethnic minority business and the employment of illegal immigrants. Entrepreneurship and Regional Development, 18(2), pp. 133-150.

Katungi, D., Neale, E. and Barbour, A., 2006. People in low-paid informal work. York: Joseph Rowntree Foundation.

Kirchgässner, G., 2011. Tax morale, tax evasion and the shadow economy, in F. Schneider (ed.), Handbook of the Shadow Economy, Cheltenham: Edward Elgar, 347-374.

Kistruck, G.M., Webb, J.W., Sutter, C.J. and Bailey, A.V.G., 2015. The double-edged sword of legitimacy in base-of-the-pyramid markets. Journal of Business Venturing, 30(3), pp. 43651.

Kloosterman, R., 2010. Matching opportunities with resources: A framework for analysing (migrant) entrepreneurship from a mixed embeddedness perspective. Entrepreneurship \& Regional Development, 22(1), pp. 25-45.

Lewis, A., 1959. The Theory of Economic Growth. London: Allen and Unwin.

Molero, J.C. and Pujol, F., 2012. Walking inside the potential tax evader's mind: tax morale does matter. Journal of Business Ethics, 105(2), pp. 151-162.

Murphy, K., 2005. Regulating more effectively: The relationship between procedural justice, legitimacy, and tax non-compliance. Journal of Law and Society, 32(4), pp. 562-589.

Neville, F., Orser, B., Riding, A. and Jung, O., 2014. Do Young Firms Owned by Recent Immigrants Outperform Other Young Firms? Journal of Business Venturing, 29(1), pp. 55-71.

Nezhyvenko, O., 2019. Indirect or Macroeconomic Methods in Measuring the Informal Economy. Journal of Applied Management and Investments, 8(4), pp. 201215
Evaluating the Relationship Between Migration and Participation in Undeclared Work

North, D.C., 1990. Institutions, Institutional Change and Economic Performance. Cambridge: Cambridge University Press.

OECD, 2012. Reducing opportunities for tax non-compliance in the underground economy. Paris: OECD.

Pasovic, E. and Efendic, A. 2018. Informal economy in Bosnia and Herzegovina - an empirical investigation. South East European Journal of Economics and Business, 13(2), pp. 112-125.

Ram, M., Edwards, P., Jones, T., 2002. Employers and Illegal Migrant Workers in the Clothing and Restaurant Sectors. London: DTI Central Unit Research.

Ram, M., Edwards, P., Jones, T., 2007. Staying Underground: Informal Work, Small Firms, and Employment Regulation in the United Kingdom. Work and Occupations, 34(3), pp. 318-344.

Ram, M., Edwards, P., Jones, T. and VillaresVarela, M., 2017. From the informal economy to the meaning of informality: Developing theory on firms and their workers. International Journal of Sociology and Social Policy, 37(7/8), pp. 361-373.

Ram, M., Jones, T. and Patton, D., 2006. Ethnic managerialism and its discontents: Policy implementation and 'ethnic minority businesses'. Policy Studies, 27(4), pp.295-309.

Ram, M., Theodorakopoulos, N., Jones, T., 2008. Forms of capital, mixed embeddedness and Somali enterprise. Work, Employment and Society, 22(3), pp. 427-446.

Rogaly, B., 2009. Spaces of work and everyday life: labour geographies and the agency of unorganised temporary migrant workers. Geography Compass, 3(6), pp. 19751987.

Routh, S., 2011. Building Informal Workers Agenda: Imagining 'Informal Employment' in Conceptual Resolution of 'Informality'. Global Labour Journal, 2(3), pp.1-12. 


\section{Articles}

Sassen, S., 2009. Cities today: A new frontier for major developments. The Annals of the American Academy of Political and Social Science, 626(1), pp. 53-71.

Schneider, F., 2013. Size and development of the shadow economy of 31 European and 5 other OECD countries from 2003 to 2013: a further decline, available at: http://www. econ.jku.at/members/Schneider/files/ publications/2013/ShadEcEurope31_Jan2013. pdf (last accessed 6 August 2019).

Schneider, F. and Williams, C.C., 2013. The Shadow Economy. London: Institute of Economic Affairs.

Sepulveda, L., Lyon, F., Botero, A. and Syrett, S., 2006. Refugees, New Arrivals and Enterprise: Their Contributions and Constraints. London: The Small Business Service.

Sepulveda, L., Syrett, S., Lyon, F., 2011. Population Superdiversity and New Migrant Enterprise: The Case of London. Entrepreneurship and Regional Development, 23(7-8), pp. 469-497.

Shahid, M.S., Rodgers, P. and Williams, C.C., 2019. Reconceptualising informal work practices: some observations from an ethnic minority community in urban UK. International Journal of Urban and Regional Research, 43(3), pp. 476-496.

Shahid, S., Rodgers, P. and Williams C.C., 2017. Evaluating the participation of an ethnic minority group in informal employment: a product of exit or exclusion? Review of Social Economy, 75(4), pp. 468-488

Siqueira, A.C.O., Webb, J.W. and Bruton, G.D., 2014. Informal Entrepreneurship and Industry Conditions. Entrepreneurship Theory and Practice, DOI: 10.1111/etap.12115.

Snyder, K., 2004. Routes to the informal economy in New York's East village: crisis, economics and identity. Sociological Perspectives, 47(2), pp. 215-40.
Thai, M.T.T. and Turkina, E., 2014. Macro-level determinants of formal entrepreneurship versus informal entrepreneurship. Journal of Business Venturing, 29(4), pp. 490-510.

Theodore, N., Blaauw, D., Schenck, C., Valenzuela Jr, A., Schoeman, C. and Meléndez, E., 2015. Day labor, informality and vulnerability in South Africa and the United States. International Journal of Manpower, 36(6), pp.807-823.

Urzi, D. and Williams, C.C., 2017. Beyond postnational citizenship: an evaluation of the experiences of Tunisian and Romanian migrants working in the agricultural sector in Sicily. Citizenship Studies, 21(1), pp. 136-150

Vershinina, N., Barrett, R. and Meyer, M., 2009. Polish Immigrants in Leicester: Forms of capital Underpinning Entrepreneurial Activity. Leicester Business School Occasional Paper 86. Leicester: De Montfort University.

Vershinina, N.A., Rodgers, P., Ram, M., Theodorakopoulos, N. and Rodionova, Y., 2018. False self employment: the case of Ukrainian migrants in London's construction sector. Industrial Relations Journal, 35(2), pp. 42-56.

Webb, J.W., Bruton, G.D., Tihanyi, L. and Ireland, R.D. (2013), "Research on entrepreneurship in the informal economy: framing a research agenda", Journal of Business Venturing, Vol. 28, pp. 598-614.

Webb, J.W., Ireland, R.D. and Ketchen, D.J., 2014. Towards a greater understanding of entrepreneurship and strategy in the informal economy. Strategic Entrepreneurship Journal, 8(1), pp. 1-15.

Webb, J.W., Tihanyi, L., Ireland, R.D. and Sirmon, D.G., 2009. You say illegal, I say legitimate: entrepreneurship in the informal economy. Academy of Management Review, 34(3), pp. 492-510. 


\section{Articles}

Williams, C.C., 2004. Cash-in-Hand Work: the underground sector and the hidden economy of favours. Basingstoke: Palgrave Macmillan.

Williams, C.C., 2006. The Hidden Enterprise Culture: entrepreneurship in the underground economy. Cheltenham: Edward Elgar.

Williams, C.C., 2014. Confronting the Shadow Economy: evaluating tax compliance behaviour and policies. Cheltenham: Edward Elgar.

Williams, C.C., 2019. The Informal Economy. Newcastle: Agenda.

Williams, C.C. and Horodnic, I.A., 2017. Tackling the informal sector in East-Central Europe. Journal of Tax Administration, 3(2), pp. 65-86.

Williams, C.C. and Horodnic, I.A., 2019. Dependent self-employment: theory, practice and policy. Cheltenham: Edward Elgar.

Williams, C.C. and Schneider, F., 2016. Measuring the Global Shadow Economy: The Prevalence of Informal Work and Labour. Cheltenham: Edward Elgar.

Williams, C.C. and Shahid, M., 2016. Informal entrepreneurship and institutional theory: explaining the varying degrees of (in) formalisation of entrepreneurs in Pakistan. Entrepreneurship and Regional Development, 28(1-2), pp. 1-25.
Evaluating the Relationship Between Migration

and Participation in Undeclared Work

Williams, C.C. and Windebank, J., 1998. Informal Employment in the Advanced Economies: implications for work and welfare. London: Routledge.

Williams, C.C. and Yang, J., 2017. Tackling falsely-declared salaries in Bulgaria: evidence from a 2015 survey. Economic Alternatives, 3, pp. 333-351

Williams, C.C., Rodgers, P. and Baric, M., 2012. International capital flows and small business development: evaluating the role of international remittances. European Journal of International Management, 6(5), pp. 486-502.

Williams, C.C., Round, J. and Rodgers, P., 2013. The Role of Informal Economies in the PostSoviet World: the end of transition? London: Routledge.

Williams, N. and Efendic, A. 2019. Internal displacement and external migration in a postconflict economy: Perceptions of institutions among migrant entrepreneurs. Journal of International Entrepreneurship, 17(4), PP. 558585.

Windebank, J. and Horodnic, I.A., 2017. Explaining participation in undeclared work in France: Lessons for policy evaluation. International Journal of Sociology and Social Policy, 37(3-4), pp. 203-217. 